\title{
SPATIAL STRUCTURE OF ECTOMYCORRHIZAL TREES IN WOODED SAVANNAS OF GUINEO-SUDANIAN ECOZONE IN WEST AFRICA
}

\author{
Houdanon RD*, Tchan IK, Laourou GA, Codjia JEI, Badou SA, Aignon LH, Boni S \& Yorou NS
}

Research Unit, Tropical Mycology and Soil-Plant-Fungi Interactions, Laboratory of Ecology, Botany and Plant Biology, Faculty of Agronomy, University of Parakou, 03 BP 125, Parakou, Benin

*roelhoudanon@yahoo.fr

Submitted January 2018; accepted June 2018

\begin{abstract}
The Guineo-Sudanian and Sudanian zones are home to predominantly ectomycorrhizal (EcM) plant communities dominated by members of the families Fabaceae (subfamily Ceasalpinioidae), Phyllanthaceae and Dipterocarpaceae. Numerous studies have shown that the aggregation of EcM trees is facilitated in part by the shared mycelial networks of EcM fungi. Mycelial networks involving mature trees would thus directly affect the survival of the seedlings of EcM trees and, thereby, the spatial structuring of the trees. In this study, we investigated the structure and spatial interactions of three vegetation types dominated by different EcM trees, namely, Isoberlinia doka, I. tomentosa and Uapaca togoensis. Three $50 \mathrm{~m} \times 50 \mathrm{~m}$ plots were installed for each vegetation type. All EcM trees present in each plot were counted for estimation of density. Ripley's second order function K was used to estimate the spatial structure of EcMs trees. Spatial distribution of trees differed between species. Repulsion occurred at scales of 1 to $5 \mathrm{~m}$ between the different EcM trees species. By sharing nutrient through mycelial network, repulsion mechanisms observed during interaction between plants should have been cancelled but this was not observed in this study.
\end{abstract}

Keywords: Spatial distribution, facilitation, repulsion, Sudanian woodland

\section{INTRODUCTION}

West Africa is phytogeographically divided into three major domains, which are Guinean Regional Endemism Centre (GRE), Sudanian Regional Endemism Centre (CRE) and GuineoSudanian transitional zone (GSZ). Whilst the GRE covers large areas of southern and costal parts of West Africa, CRE is a narrow band stretching from Mali to Uganda between the $9^{\circ}$ to $11^{\circ} \mathrm{N}$, along an annual rainfall gradient from 700 to $1200 \mathrm{~mm}$. CRE covers an area of 3.7 million $\mathrm{km}^{2}$. GSZ is located between the GRE and the CRE, approximately between latitude $7^{\circ}$ and $9^{\circ} \mathrm{N}$. In contrast to GRE, both CRE and the GSZ harbour caesalpinioiddominated woodlands and their subsequent degraded features. Woodlands of CRE and the GSZ have very simple floristic composition and is characterised by canopy trees from Fabaceae (subfamily Caesalpinioidae), Phyllanthaceae and Dipterocarpaceae (Bâ et al. 2010). The leguminous forests which once occupied considerable areas under the GSZ climate have shifted into woodlands or woody savannahs, and presently are represented by forests of other trees, including Isoberlinia doka, I. tomentosa, Burkea africana and Uapaca spp. (Bâ et al. 2011). Structurally speaking, they are mixed, woody and grassy forest types of dominant height varying between 12 and $18 \mathrm{~m}$ and whose canopy cover generally exceeds $50 \%$.

The pronounced predominance of one or two species over large areas of woodland is an essential characteristic of the CRE and GSZ. The dominant species are usually Isoberlinia legumes, Uapaca spp. and more rarely the dipterocarp Monotes kerstingii (Bâ et al. 2011). One remarkable characteristic of these species is their common ectomycorrhizal (EcM) association with fungi (Yorou et al. 2014), an obligate symbiosis between both partners to promote plant growth and survival (Smith \& Read 2008) 
Factors such as water distribution, facilitation mechanism, fire and grazing, tree clustering, lack of exogenous disturbance, slow decomposition rate of leaf litter, soils and shade tolerance are the basis of this dominance and distribution of Caesalpinaceae and Phyllantaceae in CRE and GSZ woodland (Groen et al. 2008). One key factor responsible for the monodominance and distribution of Caesalpinaceae (mostly Isoberlinia spp.), Phyllantaceae (Uapaca spp.) and Dipterocarpaceae (Monotes kerstingii) in CRE and GSZ, is the belowground mycelial network of mycorrhizal fungi that putatively promote the establishment of monodominant trees (Mc Guire 2007, McGuire et al. 2008). EcM and dual mycorrhizal (i.e. ecto- and arbuscular mycorrhizal) associations with trees can increase nutrient supplies via a more efficient exploitation of larger volumes of soils (Agerer 2001) or through the direct decomposition of leaf litter. As many monodominant trees have such associations with telluric fungi, it has been hypothesised that these associations constitutes a competitive advantage for the host trees (McGuire et al. 2008), especially as EcM networks could enhance seedling survivorship near parent trees (McGuire 2007). Nevertheless, not all species that form monodominant stands are EcM. Also, many EcM-associated tree species that are not known to form monodominant stands are present in many mixed tropical forests. One example is Aldina insignis in Central Africa, which does not outcompete other species over large areas (Peh et al. 2011). Thus, EcM associations are not a prerequisite for a species be monodominant. However, whenever present, EcM symbiosis provides sufficient explanation for monodominance (Peh et al. 2011).

Belowground mycorrhizal networks are composed of continuous fungal mycelia linking two or more plants of the same or different species (Gorzelak et al. 2015). These mycorrhizal networks provide pathways for reciprocal transfer of carbon (C) received from roots of host plant and nutrients taken up from the soil (Leake et al. 2004). They also transfer nutrients and $\mathrm{C}$ between plants interlinked by the same mycorrhizal network (Simard et al. 1997). Due to their direct impact on nutrition strategy and establishment of $\mathrm{EcM}$ forest trees, the EcM symbiosis is predicted to play an important role in density of trees, spatial distribution and forest regeneration. Thus, in the vegetation dominated by EcM plants, the repulsion mechanisms observed during interaction between certain plants (high competition for nutrients, allelopathy phenomenon, etc.) should be cancelled by interconnection and sharing of nutrients between different plants of the same and different species across the mycelial network.

In this paper, which is part of a larger study on the mutual influence of EcM fungi on their host forests in the face of microclimate variabilities, we analysed the existing spatial relationship between individuals of the same and different EcM trees using Ripley's K function. Assessing the current spatial structure of EcM trees would contribute to better understanding of the role of EcM networks in trees and forest regeneration in natural areas. This paper reports about the present representativeness and structure of EcM trees in the real environment.

\section{MATERIALS AND METHODS}

\section{Study area}

The present study was conducted in the Ouémé Supérieur Forest Reserve located between $9^{\circ} 11^{\prime}$ and $9^{\circ} 47^{\prime} \mathrm{N}$ and $1^{\circ} 58^{\prime}$ and $2^{\circ} 28^{\prime} \mathrm{E}$ (Figure 1). The study area has a rainy season from May till October which strongly contrasts with the long and severe dry season in October till April. The Ouémé Supérieur Forest Reserve is located in GSZ. The vegetation mosaic comprises woodland, wooded savannah, shrub savannah and gallery forests. The vegetation type in GSZ are dominated by members of Caesalpinioideae, Dipterocarpaceae, Phyllanthaceae and, Papilionoideae that are associated with high diversity of ectomycorrhizal fungi (Yorou et al. 2014, Bâ et al. 2011).

\section{Sampling techniques and data collection}

Three sites were investigated (Figure 1), and three permanent plots of $50 \mathrm{~m} \times 50 \mathrm{~m}$ were installed at each site. Each plot was dominated by a different EcM forest tree: I. doka (P1), I. tomentosa (P2), Uapaca togoensis or M. kerstingii (P3). A complete survey of the trees was undertaken at each plot, and the identified EcM trees were recorded, numbered and mapped according to their geographic distance $(\mathrm{X}, \mathrm{Y})$ in meters from the north-western corner of the plot. Diameters $>10 \mathrm{~cm}$ at $1.3 \mathrm{~m}$ height $(\mathrm{DBH})$ of EcM trees 

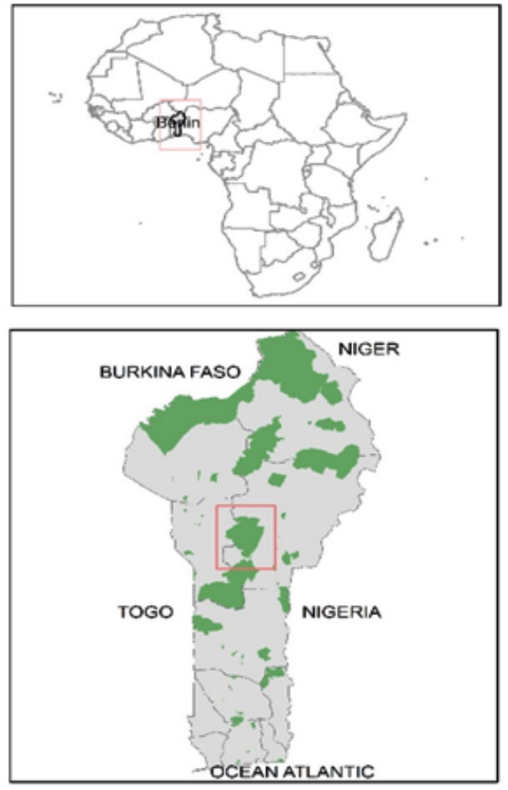

Data source: IFN/2007 Produced by BOUKARY A. Azize

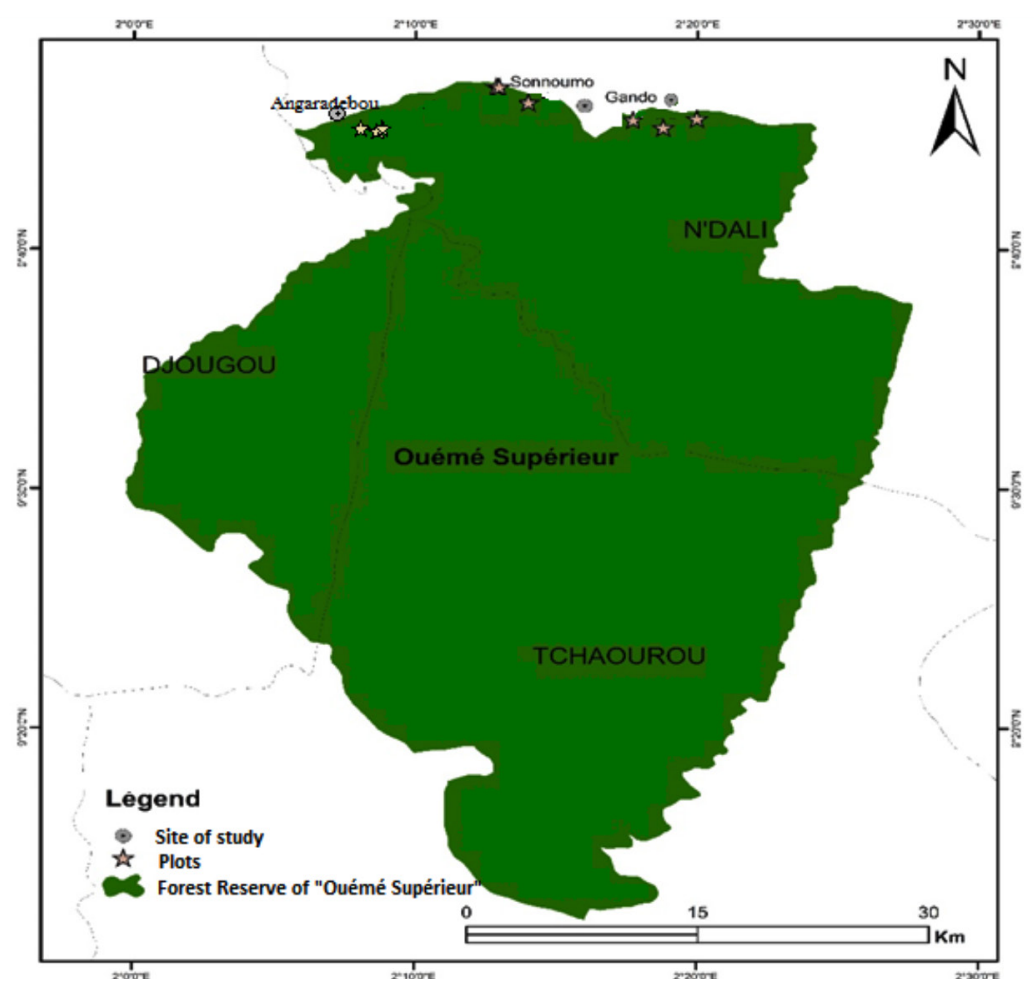

Figure 1 Ouémé Supérieur Forest Reserve (right) in Benin, with the study sites

were recorded with their circumference. Saplings (diameter $<10 \mathrm{~cm}$ at $4 \mathrm{~m}$ height) were only mapped without recording their circumference.

\section{Data analysis}

\section{Structural parameters}

Density of EcM trees in the stand $(\mathrm{N})$, is the average number of trees per EcM species per plot, expressed as stems per hectare:

$$
\mathrm{N}=\mathrm{n} / \mathrm{s}
$$

where $\mathrm{n}=$ overall number of $\mathrm{EcM}$ trees in the plot and $\mathrm{s}=$ area of the plot $=0.25$ ha. $\mathrm{G}$, basal area of the stand, is the sum of the cross-sectional areas at $1.3 \mathrm{~m}$ above ground of EcM tree on a plot and expressed in $\mathrm{m}^{2} \mathrm{ha}^{-1}$ :

$$
G=\pi / 40000 s\left(\sum_{i=1}^{n} d_{i}^{2}\right)
$$

where $d_{i}=$ diameter (in $\mathrm{cm}$ ) of the $\mathrm{i}^{\text {th }} \mathrm{EcM}$ tree of the plot.

\section{Spatial analysis model}

The analytical technique used in this work was Ripley's K(r) function (Ripley 1977). This technique makes it possible to analyse the spatial structure at different distance intervals and to detect mixed processes (for example, association at short distances and repulsion at long distances) (Fajardo et al. 2006). It is defined as the ratio of the mathematical expectation of the number of points (trees) located at a distance inferior to $r$ from an arbitrary point, to the density of the species. To estimate this function, we used the usual estimator of expectation:

$$
\mathrm{K}(\mathrm{r})=\frac{\mathrm{Ax} \sum_{\mathrm{j}=\mathrm{i}}^{\mathrm{N}} \sum_{\mathrm{j}=\mathrm{i}}^{\mathrm{N}} \mathrm{nij}}{\mathrm{N}^{2}}
$$

where $\mathrm{r}=$ distance $(\mathrm{m}), \mathrm{A}=$ area under consideration $\left(\mathrm{m}^{2}\right), \mathrm{N}=$ total number of trees, and $n_{i j}=1$ if the distance between tree $i$ and tree $j$ was less than $r$, otherwise $n_{i j}=0$. In this approach, the trees were represented by points located at the projection on the ground of the centre of their trunk. The method has the advantage of expressing spatial distribution at different scales. 
For interpretation purposes, as recommended by Collinet (1997), we used a linearised estimator of K(r) introduced by Besag (1977). The modified form of $\mathrm{K}(\mathrm{r})$ was:

$$
\mathrm{L}(\mathrm{r})=\sqrt{\frac{\mathrm{K}(\mathrm{r})}{\pi}}
$$

For any distribution, the value of $\mathrm{L}(\mathrm{r})$ gave an indication of the point seeding form at a scale of $\mathrm{r}$. To test the significance of the $\mathrm{L}(\mathrm{r})$ function, 1000 Monte Carlo simulations (Metropolis et al. 1953) were performed (Figure 2). For the production of univariate graphs, we considered only the dimensions of representativeness (r) of each species in each plot by site. The point pattern dataset function of the spatstat package 45 in R version 3.4.0 (2017) was used to perform the analysis.

\section{Calculation of intertypes}

To study the interactions between species, the analysis focused on three EcM dominant species identified by site. The test of the null hypothesis of independence distribution between groups of dominant species by plot and site was done with Ripley's intertype estimator $\mathrm{K}_{12}(\mathrm{r})$ whose modified function $\mathrm{L}_{12}(\mathrm{r})$ was (Diggle 1983):

$$
\mathrm{L}_{12}(\mathrm{r})=\sqrt{\frac{\mathrm{K}_{12}(\mathrm{r})}{\pi}}-\mathrm{r}
$$

$\mathrm{R}$ and $\mathrm{K}$ have the same meaning as explained above. The $\mathrm{L}_{12}(\mathrm{r})$ function quantified the degree and type of spatial association between size classes and between species groups. The analysis of relationship between two types of points was analysed using the Diggle (1983) intertype method. This method is similar to the previously presented Ripley method. When the value of $\mathrm{L}_{12}(\mathrm{r})$ was different from zero at a distance $\mathrm{r}$, the hypothesis of independence of the groups of species (called marks) was rejected. Statistical significance of this difference was tested by Monte Carlo simulations. Each simulation consisted of randomly assigning new coordinates to trees while leaving unchanged those of other trees (Goreaud \& Pelissier 2003). Attraction or repulsion between two trees occurred when $\mathrm{L}_{12}(\mathrm{r})$ was above or below the confidence interval respectively. The point pattern dataset function of the spatstat package was used for this purpose (Baddeley et al. 2013).

\section{RESULTS}

\section{Tree density, distribution and variation in basal area within the plots and between vegetation types}

From the location of EcM trees within the plots, we observed high density of EcM trees in different plots at site 1 compared with sites 2 and 3 (Table 1). The highest number of trees was found in the plot dominated by $I$. doka at site 1 , while the plots dominated by $I$. doka and $U$. togoensis at site 3 had the lowest EcM tree densities. Basal area of EcM trees varied greatly between the plots and the sites from $9.86 \mathrm{~m}^{2} \mathrm{ha}^{-1}$ in plot 2 at site 1 to $4.77 \mathrm{~m}^{2} \mathrm{ha}^{-1}$ in plot 3 at the site 3 (Table 1 ).

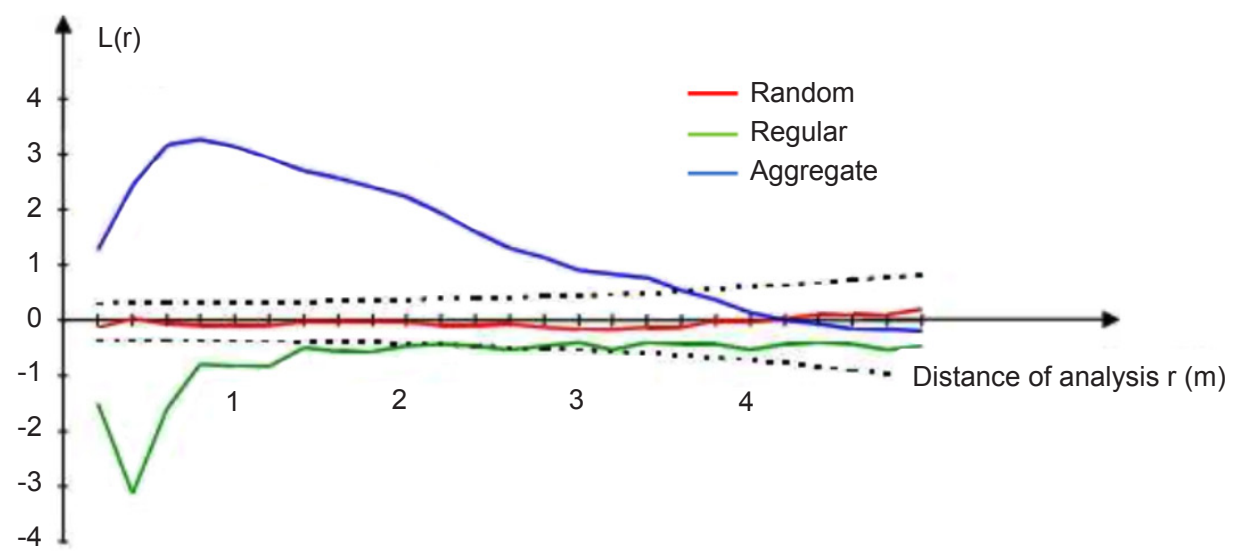

Figure 2 Example Ripley curves for regular, random and aggregated distribution 
Table 1 Densitiy and basal area of EcM trees by site and by plot

\begin{tabular}{|c|c|c|c|c|c|c|c|}
\hline \multirow[t]{2}{*}{ Site } & \multirow[t]{2}{*}{ Species } & \multicolumn{3}{|c|}{ Density (number $3600 \mathrm{~m}^{-2}$ ) } & \multicolumn{3}{|c|}{ Basal area $\left(\mathrm{m}^{2} \mathrm{ha}^{-1}\right)$} \\
\hline & & Plot 1 & Plot 2 & Plot 3 & Plot 1 & Plot 2 & Plot 3 \\
\hline \multirow[t]{4}{*}{ Site 1} & Isoberlinia doka & 51 & 8 & 25 & 8.46 & 9.86 & 6.37 \\
\hline & Isoberlinia tomentosa & 1 & 33 & 4 & & & \\
\hline & Monotes kerstingii & 15 & 16 & 44 & & & \\
\hline & Uapaca togoensis & 41 & - & 22 & & & \\
\hline \multirow[t]{4}{*}{ Site 2} & Isoberlinia doka & 91 & - & 17 & 8.40 & 6.39 & 5.40 \\
\hline & Isoberlinia tomentosa & - & 57 & - & & & \\
\hline & Monotes kerstingii & 3 & 2 & - & & & \\
\hline & Uapaca togoensis & 2 & 1 & 85 & & & \\
\hline \multirow[t]{4}{*}{ Site 3} & Isoberlinia doka & 46 & 13 & - & 8.23 & 7.20 & 4.77 \\
\hline & Isoberlinia tomentosa & - & 17 & - & & & \\
\hline & Monotes kerstingii & 1 & - & 6 & & & \\
\hline & Uapaca togoensis & 4 & - & 74 & & & \\
\hline
\end{tabular}

Spatial distribution of trees and their interdependencies

For site 1 , analyses showed that the $\mathrm{L}(\mathrm{r})-\mathrm{r}$ curves calculated for all species remained outside the confidence envelopes from 0 to $10 \mathrm{~m}$ radius, and thereafter remained close but within the confidence envelopes (Figure 3a). This indicated heterogeneity in the spatial distribution of trees within the study area. For site 2 , the curve remained within the confidence interval, regardless of distance and confirmed the homogeneity of the trees distribution and their random character (Figure 3b). The curve for site 3 remained within the confidence interval and showed the homogeneity and random distribution of trees at this site (Figure 3c).

\section{Intraspecific structures of each species within the plots and between the sites}

Isoberlinia doka had regular distribution over a $1 \mathrm{~m}$ range (Figure $4 \mathrm{a}$ ) in plot 1 of site 1 . Beyond the $1 \mathrm{~m}$ radius, I. doka showed random distribution. Uapaca togoensis trees were distributed in aggregates from 2 to $12 \mathrm{~m}$ radius. Monotes kerstingii had regular distribution at $1.5 \mathrm{~m}$ range and random distribution $\geq 1.5 \mathrm{~m}$ radius. Isoberlinia tomentosa in plot 2 at site 1 showed regular distribution for $r<1 \mathrm{~m}$ and random distribution at greater distances while distribution of $M$. kerstingii was aggregative for $\mathrm{r}<2.5 \mathrm{~m}$ and random at greater distances (Figure 4b). In plot 3 of site 1 (Figure 4c), $M$. kerstingii had regular distribution for $\mathrm{r}<1 \mathrm{~m}$ and random distribution at greater distances. In the same habitat, U. togoensis showed aggregative distribution for $\mathrm{r}<6 \mathrm{~m}$ and random distribution at greater distances.

The distribution of $I$. doka in plot 1 at site 2, (Figure 5 a) showed regular distribution up to $0.5 \mathrm{~m}$ range and random distribution outside this range. The population of $I$. tomentosa in plot 2 at the same site had random distribution (Figure $5 \mathrm{~b}$ ). In plot 3 , distribution of $U$. togoensis was aggregative (Figure $5 \mathrm{c}$ ) while $I$. doka had aggregative distribution for $\mathrm{r}<0.5 \mathrm{~m}$ and random distribution at greater distances.

At site 3, I. doka showed random distribution in plot 1 (Figure 6a). Regular distribution was observed for I. doka and I. tomentosa for $\mathrm{r}<1 \mathrm{~m}$ and $\mathrm{r}<2 \mathrm{~m}$ respectively and random distribution for greater distances in plot 2 (Figure 6b). Uapaca togoensis displayed aggregated distribution (Figure 6c) in plot 3. Table 2 summarises the distribution of all EcM trees at different sites and plots.

\section{Interspecific structures of dominant EcM tree species}

Distribution parameters between EcM tree species taken two by two per plot at each site were studied using intertype estimator. At all study sites, EcM trees species maintained distancing relationship (i.e. repulsive interaction between individuals of two different species). At site 1, repulsion in plot 1 between $M$. kerstingii and $U$. togoensis was about $1 \mathrm{~m}$ and that between I. doka and M. kestingii was about $2 \mathrm{~m}$. Repulsion between $I$. doka and $U$. togoensis was $1 \mathrm{~m}$ at site 1 but it was $0.5 \mathrm{~m}$ at site 2 in plot 3. Repulsion between I. tomentosa and M. kerstingii at site 1 in plot 2 was $1.5 \mathrm{~m}$ while that between $U$. togoensis 

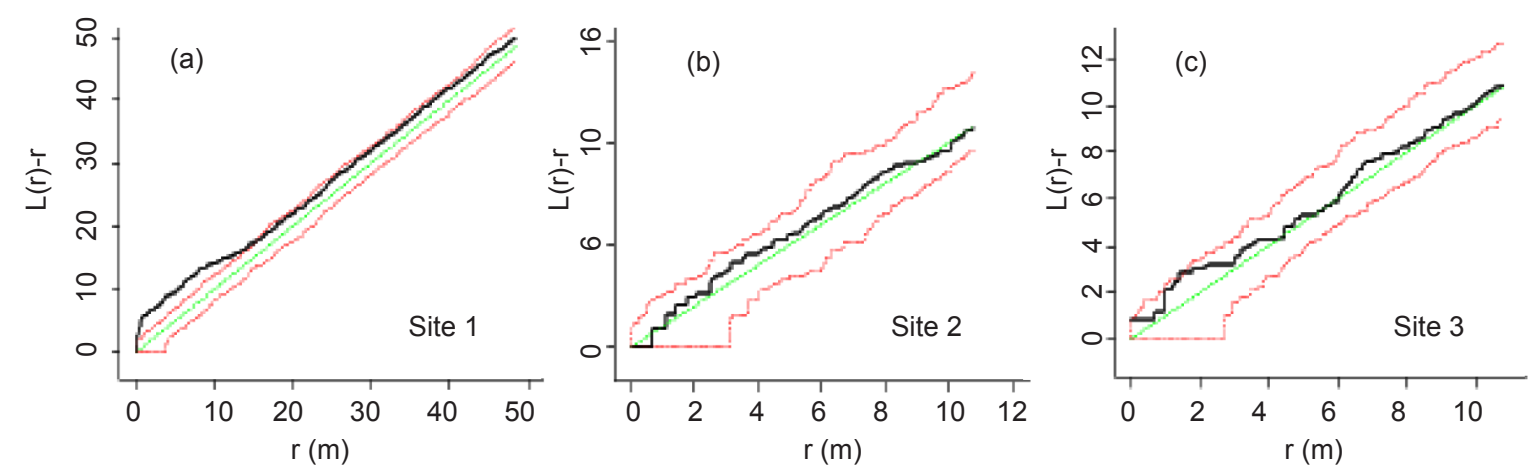

Figure $3 \mathrm{~L}(\mathrm{r})$ curves (black line) for spatial distribution of trees of sites 1, 2 and 3 and their corresponding confidence envelopes (dotted line)
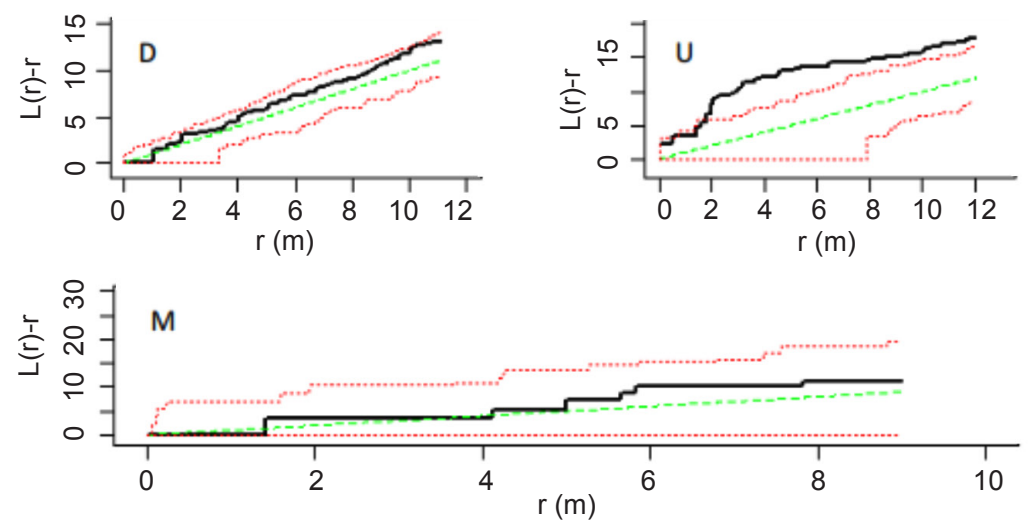

(a)
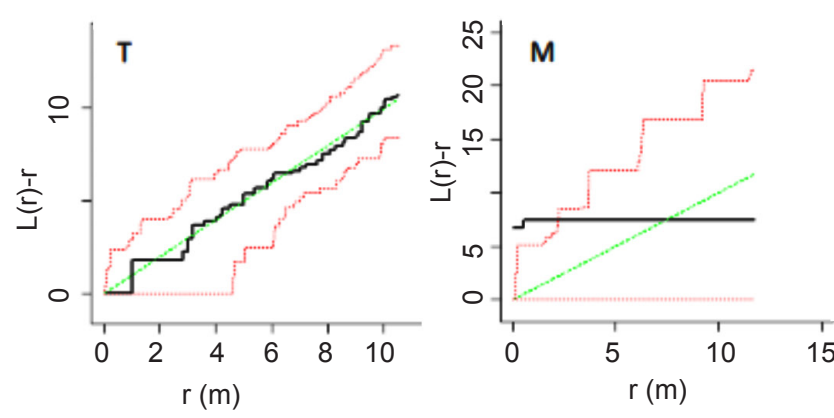

(b)
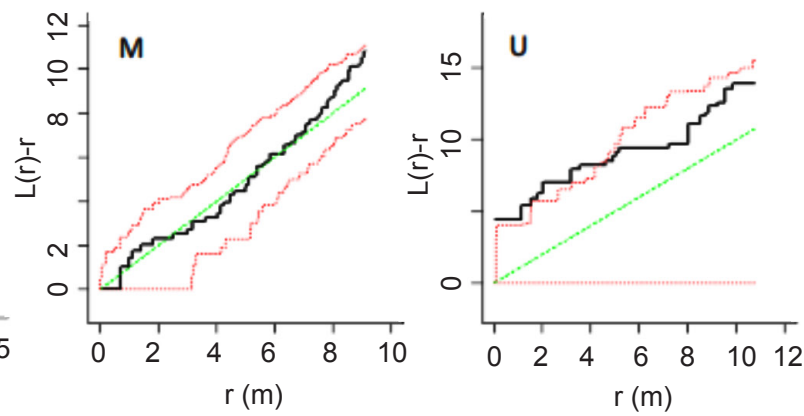

(c)

Figure 4 Spatial distribution of Isoberlinia doka (D), I. tomentosa $(\mathrm{T})$, Monotes kerstingii $(\mathrm{M})$ and Uapaca togoensis (U) in plots (a) 1, (b) 2 and (c) 3 at site 1 with Ripley's function; L(r) curves (black line) and confidence envelopes (dotted line) are based on the distance $r$

and $M$. kestingii at site 1 , plot 3 was $1 \mathrm{~m}$. Repulsion was more pronounced between $I$. doka and I. tomentosa at site 3 , plot 2 , i.e. about $4.5 \mathrm{~m}$. Table 3 summarises the interspecific structures of dominant EcM trees.

\section{DISCUSSION}

The results of our study confirmed the coexistence of the four EcM species, i.e. $M$. kerstingii, U. togoensis with I. doka and I. tomentosa. Monotes kerstingii, the only Dipterocarpaceae in West Africa, occurs in association with mixed stands of Isoberlinia spp. (Bâ et al. 2010). Uapaca togoensis has also been frequently identified in woodlands and savannahs dominated by Isoberlinia spp. Isoberlinia spp. woodland is one of the two major plant communities (the other being Vitellaria paradoxa woodland) in West Africa (Downing 2010). Isoberlinia stands are young, 
Table 2 Distribution of EcM trees at different sites and plots of this study

\begin{tabular}{|c|c|c|c|c|c|c|c|c|c|}
\hline \multirow[t]{2}{*}{ Species } & \multicolumn{3}{|c|}{ Site 1} & \multicolumn{3}{|c|}{ Site 2} & \multicolumn{3}{|c|}{ Site 3} \\
\hline & Plot 1 & Plot 2 & Plot 3 & Plot 1 & Plot 2 & Plot 3 & Plot 1 & Plot 2 & Plot 3 \\
\hline $\mathrm{D}$ & $\begin{array}{l}\text { Regular at } \\
1 \mathrm{~m}\end{array}$ & - & - & $\begin{array}{l}\text { Regular } \\
\text { at } 0.5 \mathrm{~m}\end{array}$ & - & $\begin{array}{c}\text { Aggregate } \\
\text { at } 0.5 \mathrm{~m}\end{array}$ & Random & $\begin{array}{l}\text { Regular } \\
\text { at } 1 \mathrm{~m}\end{array}$ & - \\
\hline M & $\begin{array}{c}\text { Regular at } \\
1.5 \mathrm{~m}\end{array}$ & $\begin{array}{c}\text { Aggregate } \\
\text { at } 2.5 \mathrm{~m}\end{array}$ & $\begin{array}{c}\text { Regular at } \\
0.75 \mathrm{~m}\end{array}$ & - & - & - & - & - & - \\
\hline $\mathrm{U}$ & Aggregate & - & $\begin{array}{c}\text { Aggregate } \\
\text { at } 5 \mathrm{~m}\end{array}$ & - & - & $\begin{array}{c}\text { Aggregate } \\
\text { at } 3 \mathrm{~m} \text { et }> \\
10 \mathrm{~m}\end{array}$ & - & - & Aggregate \\
\hline $\mathrm{T}$ & - & $\begin{array}{c}\text { Regular at } \\
1 \mathrm{~m}\end{array}$ & - & - & Random & - & - & $\begin{array}{c}\text { Regular } \\
\text { at } 2 \mathrm{~m}\end{array}$ & - \\
\hline
\end{tabular}

$\mathrm{D}=$ Isoberlinia doka, $\mathrm{M}=$ Monotes kerstingii, $\mathrm{U}=$ Uapaca togoensis and $\mathrm{T}=$ Isoberlinia tomentosa

Table 3 Mode of distribution of EcM species taken two by two per plot at each study site by radius reach

\begin{tabular}{|c|c|c|c|c|c|c|c|c|c|}
\hline \multirow[t]{2}{*}{ Species } & \multicolumn{3}{|c|}{ Site 1} & \multicolumn{3}{|c|}{ Site 2} & \multicolumn{3}{|c|}{ Site 3} \\
\hline & Plot 1 & Plot 2 & Plot 3 & Plot 1 & Plot 2 & Plot 3 & Plot 1 & Plot 2 & Plot 3 \\
\hline D:M & $\begin{array}{c}\text { Repulsive at } \\
1.8 \mathrm{~m}\end{array}$ & - & - & - & - & $\begin{array}{l}\text { Repulsive } \\
\text { at } 0.5 \mathrm{~m}\end{array}$ & - & - & - \\
\hline $\mathrm{D}: \mathrm{U}$ & $\begin{array}{c}\text { Repulsive at } \\
1.5 \mathrm{~m}\end{array}$ & - & - & - & - & - & - & - & - \\
\hline $\mathrm{D}: \mathrm{T}$ & - & - & - & - & - & - & - & $\begin{array}{l}\text { Repulsive } \\
\text { at } 1.8 \mathrm{~m}\end{array}$ & $\begin{array}{c}\text { Repulsive at } \\
4.5 \mathrm{~m}\end{array}$ \\
\hline $\mathrm{M}: \mathrm{U}$ & $\begin{array}{c}\text { Repulsive at } \\
1.5 \mathrm{~m}\end{array}$ & - & $\begin{array}{l}\text { Repulsive } \\
\text { at } 1.8 \mathrm{~m}\end{array}$ & - & - & - & - & - & - \\
\hline $\mathrm{M}: \mathrm{T}$ & - & $\begin{array}{l}\text { Repulsive } \\
\text { at } 1.8 \mathrm{~m}\end{array}$ & - & - & - & - & - & - & - \\
\hline
\end{tabular}

$\mathrm{D}=$ Isoberlinia doka, $\mathrm{M}=$ Monotes kerstingii, $\mathrm{U}=$ Uapaca togoensis and $\mathrm{T}=$ Isoberlinia tomentosa

with individuals aged 30 to 40 years, indicating a very dynamic system. This is highlighted in this study by the low basal area of the trees, varying from 4.77 to $9.86 \mathrm{~m}^{2} \mathrm{ha}^{-1}$. The predominance of $U$. togoensis and M. kerstingii in Isoberliniadominated stands could be explained by two essential factors, namely, the canopy effect on the reduction of fire frequency (Hennenberg et al. 2005) and the mycelial network effect (Mcguire 2007). Isoberlinia species are good early coloniser as it can reproduce from root suckers (in secondary succession) and it grows quickly (Fonton et al. 2012). Once the Isoberlinia spp. get large enough, their canopy are able to reduce the presence of grass in the undergrowth, which in turn reduces the fuel available for burning while providing a cooler, wetter environment that can withstand fire (Nangendo et al. 2005). This environment will encourage the growth of other woodland understorey species such as U. togoensis, M. kerstingii, Gardenia spp., Pteleopsis suberosa and Piliostigma thonningii (Akpado 2000). The predominance of EcM species, notably $U$. togoensis and M. kerstingii, in Isoberliniadominated stands could also be explained by the positive effect of the mycelial network on the survival and growth of EcM seedlings. It has been reported that almost $100 \%$ of the surviving seedlings of EcM trees planted on EcM myceliumrich substrates, were all colonised by EcM fungi (Mcguire 2007, Diédhiou et al. 2010). Thus, it has been suggested that the connection of seedlings to the existing mycorrhizal network is an important advantage. As EcM symbiosis in general is not species-specific, the EcM mycorrhizal network will connect and facilitate the establishment of any EcM tree species. This may explain the presence of $U$. togoensis and $M$. kerstingii in Isoberlinia-dominated stands.

This study generally showed random distribution of EcM trees with aggregates varying in radius from 1 to $10 \mathrm{~m}$. The aggregate 

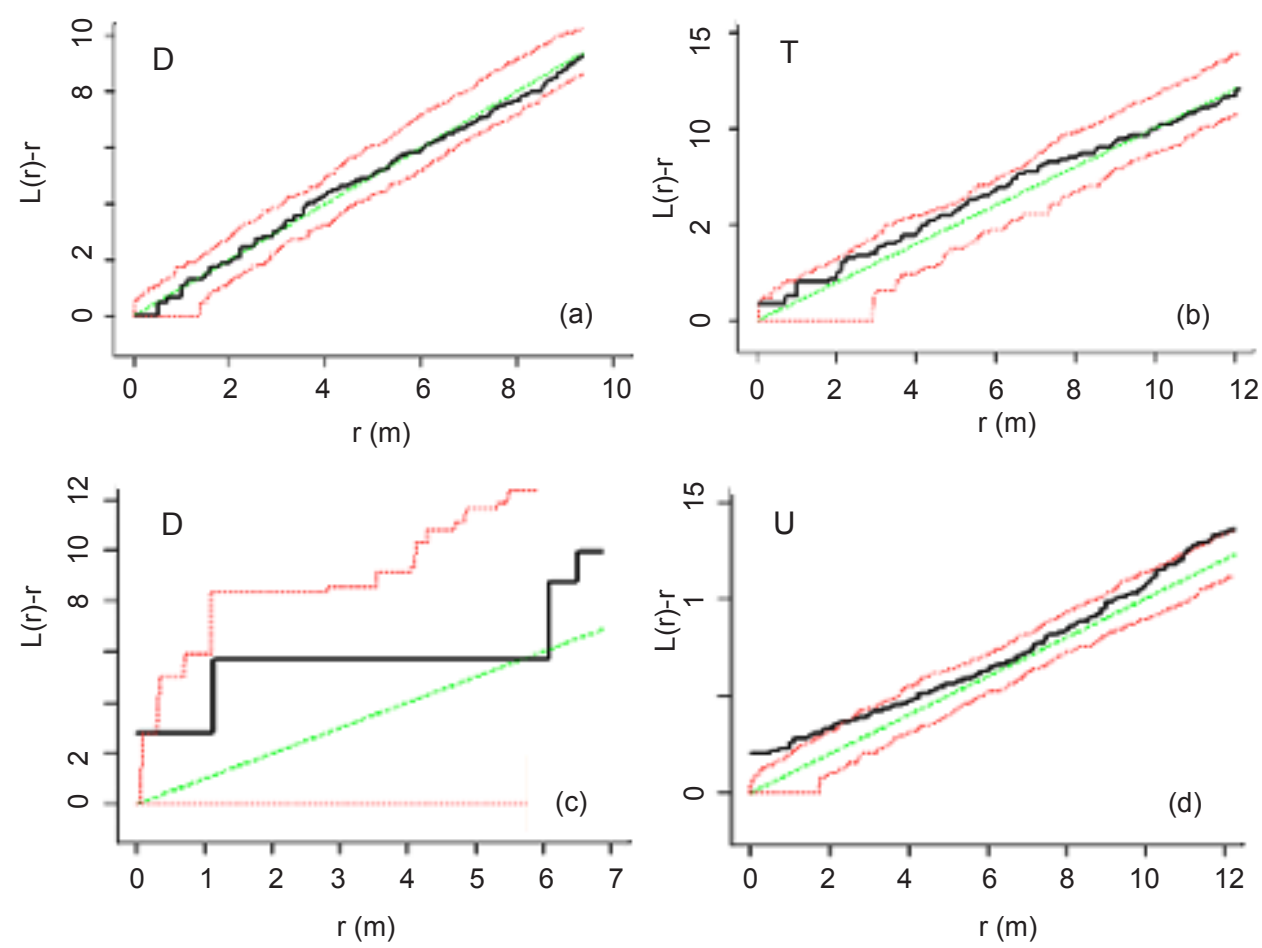

Figure 5 Spatial distribution of EcM trees at site 2; (a) Isoberlinia doka (D) in plot 1, (b) I. tomentosa (T) in plot 2 and (c) I. doka (D) and (d) Uapaca togoensis (U) in plot 3; L(r) curves (black line) and confidence envelopes (dotted line) are based on the distance $r$

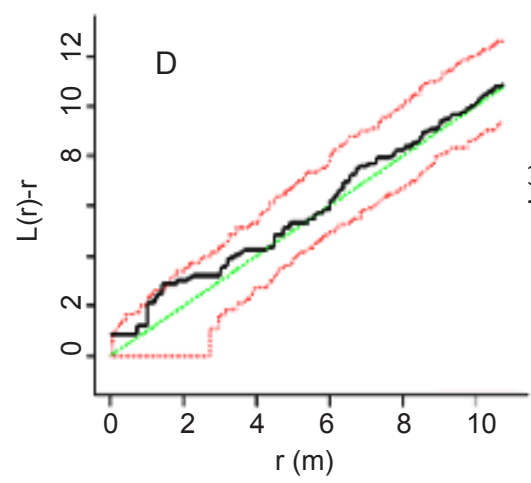

(a)

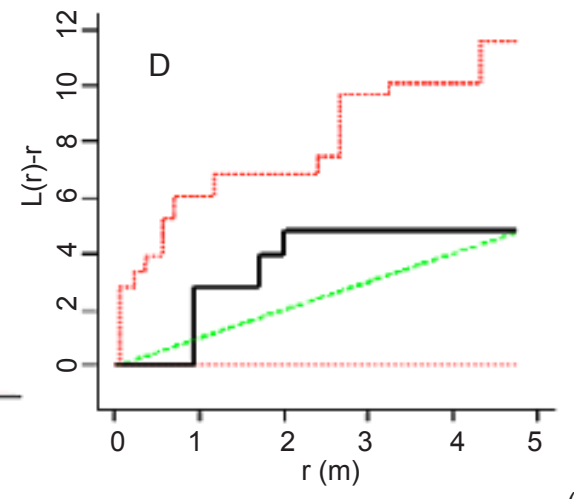

(b)
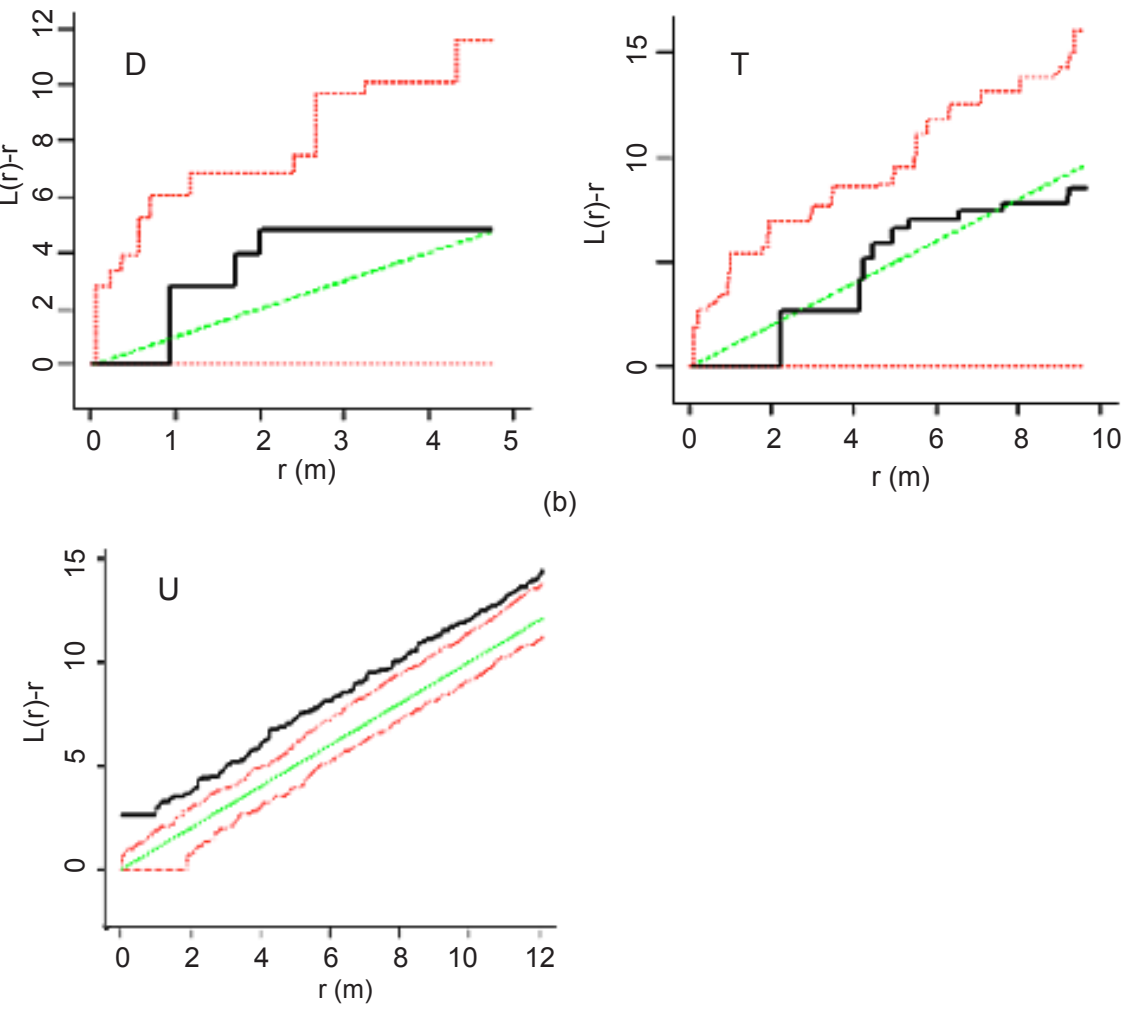

(c)

Figure 6 Spatial distribution of EcM trees at site 3; (a) Isoberlinia doka (D) in plot 1, (b) I. doka (D) and I. tomentosa $(\mathrm{T})$ in plot 2 and (c) Uapaca togoensis (U) in plot 3 
distribution of trees in CRE and GSZ ecozones is limited to small patches (Fonton et al. 2012). Isoberlinia doka, M. kerstingii and especially $U$. togoensis had aggregate distribution, as shown by Fonton et al. (2012). Similarly, the authors observed the stands of $M$. kerstingii in small aggregates in ecologically similar area in northern Benin. The aggregate distribution of $U$. togoensis induced greater diversity of EcM fungi (De Kesel et al. 2002) than under more disseminated species.

The distribution of trees in relation to each other showed a distancing relationship, which was much more pronounced between $I$. doka and I. tomentosa. Numerous studies supported the distancing relationship of native CRE and GSZ forest trees. For example, the distribution of Parkia biglobosa and Vitellaria paradoxa, Vitex doniana, Anogeissus leiocarpa and Tectona grandis are characterised by a repulsion process of about 1 to $10 \mathrm{~m}$, meaning that the probability of finding the other tree species is lower within 1-10 $\mathrm{m}$ from the first tree species (Dotchamou et al. 2016). The repulsion process has been attributed to dissemination strategy of the trees (Fonton et al. 2012), and also the allelopathy phenomenon (Dale 1999) and morphology of the trees (Dotchamou et al. 2016). Nevertheless, EcM symbiosis could strongly affect the distribution of forest trees in their natural environment. The extent of fungal mycelium in the soil is large and the mutualisms between fungal species and host plants are usually diffuse, enabling the formation of mycorrhizal network (Gorzelak et al.2015). Mycorrhizal networks can influence the physiology (Wu et al. 2001), growth (Teste et al. 2010) and defense chemistry (Song et al. 2010) of plants. Ectomycorrhizal saplings that are connected via mycorrhizal network can rapidly modify their behaviour in response to fungal colonisation and interplant biochemical communication (Gorzelak et al. 2015). Mycorrhizal networks can influence sapling establishment and enhance seedlings survival (Nara 2006, Teste et al. 2008). If EcM networks enhance seedling survival, it could be predicted that a positive dependent distance of seedling survival will be observed in these systems. This prediction was based on the assumption that seedlings survived best near to parent trees, where they would have increased access to a common EcM network. Over time, this positive distance-dependence will maintain a low diversity, monodominant forest by promoting conspecific aggregation of EcM trees (McGuire 2007). However, it was reported that survival rates of EcM seedlings were better (up to $100 \%$ ) when seedlings were located further away (2.5 to $5 \mathrm{~m}$ ) from the adult trees (Teste et al. 2008). On the contrary, Diédhiou et al. (2010) suggested a net positive impact for seedling established close to adult trees. Seedlings can be favoured by adult trees through the presence of the mycelial network, regardless of the distance between them (Mcguire 2007). The results of these past studies explained the distance relation between adult EcM trees and seedlings whereby without disturbance of the habitats, we could observe the same distribution between adult trees.

In the present study, it is premature to conclude how different individuals of the same or different tree species can benefit from the mycorrhizal network in such a way as to lead to a repulsive distribution. Our results could be from the recurrent debate whether EcM trees share the same or different EcM fungi. At the same time, the putative impact of mycorrhizal network on the present distribution of forest trees remains open. Long-term ( $4-5$ years) monitoring of fungal communities, as well as the combined molecular typing methods and application of stable isotopes seems necessary to unravel the complexity of EcM community and its potential impact on spatial structure of EcM trees in CRE and GSZ ecozones.

\section{CONCLUSIONS}

This study has shown that spatial distribution of ectomycorrhizal trees in adulthood is essentially aggregative within the same species but repulsive between species. These results seemed odd especially since the transfer of nutrients through the mycelial network annihilated the cause of repulsion observed between different species in the Sudanian zone. In order to take into account the repulsive behaviour in enrichment processes based on valuable species studied in the Sudanese region, we suggest the adoption of minimum spacing of 1 to $2 \mathrm{~m}$ between trees of the same species (except $U$. togoensis) and 1 to $4.5 \mathrm{~m}$ between different species in the wooded areas of the Sudanese zone. However, early mortality rates and poor growth of the species concerned suggest that these spacings may not be optimal. 


\section{AKNOWLEDGMENTS}

The present work is part of a larger research project entitled 'The diversity and natural productions of locally harvested mushrooms in light of climatic change in West Africa' financed by FORMAS (grant no. 226-2014-1109) to whom we address our sincere thanks. We acknowledge the help and hospitality of the local people and forest guides from Gando, Sonnoumon and Angaradebou (Ndali region, central Benin). We also thank Boni Yacoubou from the University of Parakou, Benin for his assistance in the selection of vegetation types, as well as Brendan Furneaux and Martin Ryberg from the Department of Organismal Biology, Faculty of Science and Technology, Uppsala University for their time and effort in helping us prepare this paper.

\section{REFERENCES}

Agerer R. 2001. Exploration types of ectomycorrhizae. A proposal to classify ectomycorrhizal mycelial systems according to their patterns of differentiation and putative ecological importance. Mycorrhiza 11: 107114. https://doi.org/10.1007/s005720100108.

Akpado L. 2000. Etude sur les formation forestieres naturelles et sur les plantations forestieres au Benin. CE-FAO-Programme Partenariat (1998-2000). Projet GCP/INT/679/EC.

BÂ AM, Diedhiou GA, Prin Y, Galiana A \& Duponnois R. 2010. Management of ectomycorrhizal symbionts associated to useful exotic tree species to improve reforestation performances in tropical Africa. Annals of Forest Science 67: 301. doi: 10.1051/forest/2009108.

Bâ AM, Duponnois R, Diabate M \& Dreyfus B. 2011. Les champignons ectomycorrhiziens des arbres forestiers en Afrique de l'Ouest. IRD, Marseille.

Baddeley A, Turner R, Mateu J, Bevan A. 2013. Hybrids of Gibbs point process models and their implementation. Journal of Statistical Software 55: 1-43.

Bellefontaine R, Gaston A, Petrucci Y. 1997. Aménagement des Forêts Naturelles des Zones Tropicales Sèches. FAO, Rome.

BESAG J. 1977. Contribution to the discussion of Dr Ripley's paper. Journal of the Royal Statistical Society B 39: 193-195.

Collinet F. 1997. Essai de regroupement des principales espèces structurantes d'une forêt dense humide d'après l'analyse de leur répartition spatiale. Forêt de Paracou, Guyane. PhD thesis, Université Claude Bernard Lyon I, Villeurbanne.

DAle MRT. 1999. Spatial Pattern Analysis in Plant Ecology. Cambridge University Press, New York.

De Kesel A, Codjia JC \& Yorou SN. 2002. Guide des Champignons Comestibles du Bénin. Jardin Botanique de National de Belgique et CECODI, Cotonou

Diédhiou AG, Selossé MA, Galiana A et al. 2010. Multi-host ectomycorrhizal fungi are predominant in a Guinean tropical rainforest and shared between canopy trees and seedlings. Environmental Microbiology 12: 2219-2232.

Diggle JP. 1983. Statistical Analysis of Spatial Point Patterns. Academic Press, New York.

Dotchamou OFT, Atindogbe G, Azihou AF \& Fonton NH. 2016. Caractérisation de la Répartition Spatiale des arbres de Parkia biglobosa (Jacq.) R. Br. Au Bénin. Science de la vie, de la terre et agronomie 4: 59-67.

Downing T. 2010. The role of late fire in land cover change in the Ouémé Supérieur Forest, Benin. PhD thesis, University of Minnesota, Minneapolis. doi: 10.13140/RG.2.1.4576.8728.

Fajardo A, Goodburn JM \& Graham J. 2006. Spatial patterns of regeneration in managed uneven-aged ponderosa pine/Douglas-fir forests of Western Montana, USA. Forest Ecology and Management 223: 255-266.

Fonton HN, Atindogbe G, Fandohan B, Lejeune P \& Ligot G. 2012. Structure spatiale des arbres des savanes boisées et forêts claires soudaniennes implication pour les enrichissements forestiers. Biotechnologie Agronomie Société Environnement 16: 429-440.

Goreaud F \& Pélissier R. 2003. Avoiding misinterpretation of biotic interactions with the intertype K12-function: population independence vs. random labeling hypotheses. Journal of Vegetation Science 14: 681-692.

Gorzelak AM, Asay AK, Pickles BJ \& Simard SW. 2015. Inter-plant communication through mycorrhizal networks mediates complex adaptive behavior in plant communities. AoB Plants 7: plv050.doi:10.1093/ aobpla/plv050.

Groen TA, Van Langevelde F, Van De Vijver CADM, Govender N \& Prins HHT. 2008. Soil clay content and fire frequency affect clustering in trees in South African savannas. Journal of Tropical Ecology 24: 269-279.

Hennenberg KJ, Goetze D, Minden V, Traoré D \&Porembski S. 2005. Size class distribution of Anogeissus leiocarpus (Combretaceae) along forest-savanna ecotones in northern Ivory Coast. Journal of Tropical Ecology 21: 273-281.

Leake J, Johnson D, Donnelly D, Muckle G, Boddy L \& READ D. 2004. Networks of power and influence: the role of mycorrhizal mycelium in controlling plant communities and agroecosystem functioning. Mycorrhiza 82: 1016-1045.

MCGUIRE KL. 2007. Common ectomycorrhizal networks may maintain monodominance in a tropical rain forest. Ecology 88: 567-574.

Mcguire KL, Henkel TW, De La Cerda GI, Villa G, Edmund F \& ANDREW C. 2008. Dual mycorrhizal colonization of forest-dominated tropical trees and the mycorrhizal status of non-dominant tree and liana species. Mycorrhiza 18: 217-222.doi: 10.1007/s00572-0080170-9.

Metropolis N, Rosenbluth AW, Rosenbluth MM, Teller AH \& Teller E. 1953. Equation of state calculations by fast computing machines. Journal of Chemical Physics 21: $1087-1092$.

NARA K. 2006. Ectomycorrhizal networks and seedling establishment during early primary succession. New Phytologist 169:169-178. doi: 10.1111/j.14698137.2005.01545.x.

Nangendo G, Stein A, Steege H \& Bongers F. 2005. Changes in woody plant composition of three vegetation types 
exposed to a similar fire regime for over 46 years. Forest Ecology and Management 217: 351-364.

Peh KSH, Lewis SL \& Lloyd J. 2011.Mechanisms of monodominance in diverse tropical tree-dominated systems. Journal of Ecology 99: 891-898.

RIPLEY BD. 1977. Modeling spatial patterns. Journal of the Royal Statistical Society B 39: 172-212.

Simard SW, Perry DA, Jones MD, Myrold DD, Durall DM \& Molina R. 1997. Net transfer of carbon between ectomycorrhizal tree species in the field. Nature 388 : $579-582$.

Smith SE \& ReAd DJ. 2008. Mycorrhizal Symbiosis. Third edition. Academic Press, London.

Song YY, Zeng RS, Xu JF, Li J, Shen X \&Yindegowg. 2010. Interplant communication of tomato plants through underground common mycorrhizal networks. PLoS ONE 5: e13324. https://doi.org/10.1371/journal. pone.0013324.
Teste FP, Simard SW, Durall DM, Guy RD, Jones MD \& Schoonmaker AL. 2008. Access to mycorrhizal networks and roots of trees: importance for seedling survival and resource transfer. Ecology 90: 2808-2822.

Teste FP. Simard SW, Durall DM, Guy RD \& Berch SM. 2010. Net carbon transfer between Pseudotsuga menziesii var. glauca seedlings in the field is influenced by soil disturbance. Journal of Ecology 98: 429-439.

Wu B, Nara K \& Hogetsu T. 2001.Can ${ }^{14}$ C-labeled photosynthetic products move between Pinus densiflora seedlings linked by ectomycorrhizal mycelia? New Phytologist 149: 137-146. doi: 10.1046/ j.1469-8137.2001.00010.x.

Yorou SN, Kone AN, De Kesel A, Guissou ML \& Ekue MR. 2014. Biodiversity and sustainable use of wild edible fungi in the Sudanian centre of endemism: a plea for their valorisation. Pp 241-270 in Bâ AM et al. (ed) Ectomycorrhizal Symbioses in Tropical and Neotropical Forests. CRC Press, Boca Raton. 